\title{
A study to isolate various bacteria causing osteomyelitis in a tertiary health care setup
}

\author{
Kumar P S. ${ }^{1}$, Chandra T. J. 2* \\ DOI: https://doi.org/10.17511/ijoso.2020.i01.07 \\ 1 Sunil Kumar P, Associate Professor, Department of Orthopedics, Konaseema Institute of Medical Sciences, Amalauram, Andhra Pradesh, \\ India. \\ 2* Jaya Chandra T., Associate Professor, Department of Microbiology, GSL Medical College, Rajahmundry, Andhra Pradesh, India.
}

Introduction: Osteomyelitis (OM), an inflammation of bone or bone marrow caused by various infectious agents, can cause any age. With this, a study was taken to isolate various bacterial etiological agents that cause OM. Material and Methods: It was a laboratory-based study, conducted in the Department of Microbiology, GSL Medical College from June to Nov 2019. Individuals of all ages, both genders, clinically, radiologically confirmed cases of OM were included in the study. Bone, tissue, and swabs collected with utmost sterile precautions were considered, cultured as per the standard methods. Antibiotic susceptibility test was performed for various pathogenic isolates using Kirby Bauer disc diffusion method; $\mathrm{P}<0.05$ was considered statistically significant. Results: During the study period a total of 72 samples were collected, 61 were culture positive (CP). Age-wise, maximum (18\%) CP results were identified in $31-40$ years of age group followed by 41-50 years group. Gram-negative rods were isolated maximum (59\%) and Staph. aureus was the maximum isolate. Conclusion: OM can occur at any age and there is no gender difference. Staph. aureus was a common isolate followed by Pseudomonas.

Keywords: Age, Isolate, Maximum, Predominant

Corresponding Author

Jaya Chandra T., Associate Professor, Department of Microbiology, GSL Medical College, Rajahmundry, Andhra Pradesh, India.

Email: chanduthegreat2014@gmail.com
How to Cite this Article

To Browse
Kumar PS, Chandra TJ. A study to isolate various bacteria causing osteomyelitis in a tertiary health care setup. Surgical Review Int J Surg Trauma Orthoped. 2020;6(1):40-44.

Available From

https://surgical.medresearch.in/index.php/ijoso/artic le/view/156

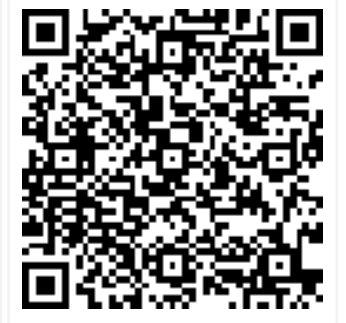

\section{Introduction}

Osteomyelitis (OM), an inflammation of bone or bone marrow caused by various infectious agents [1]. Hematogenous or direct inoculation in bone is the main route of transmission of OM. Based on the time duration, it may be acute or chronic. Acute OM will respond well to the treatment, rarely

Manuscript Received 10-01-2020

Conflict of Interest No

$\begin{array}{cc}\text { Manuscript Received } & \text { Review Round } 1 \\ 10-01-2020 & 20-01-2020 \\ \text { Conflict of Interest } & \text { Funding } \\ \text { No } & \text { Nil }\end{array}$

Surgical intervention is required. Whereas chronic $O M$ is tough to treat, and surgical intervention is required $[2,3]$.

Chronic OM was first reported Hioppcrates era [4]. It was reported that chronic OM is the condition that commonly affects tibia and femur, whereas acute OM also affects femur ad tibia $[5,6]$ and was reported to be 
Common among pediatrics affect 5 to 10,000 children per year [7].

Various techniques such as increased erythrocyte sedimentation rate, elevated $C$ reactive protein and so on are available for the diagnosis of OM. But these are non-specific, so mainly useful in treatment monitoring. Higher imaging studies such as CT / MRI are used to find the necrotic bony area because the routine $X$-ray can help to find the lytic area.

In spite of the availability of various techniques, culture was the gold standard method to establish OM [8]. Here, a tissue biopsy is the ideal sample rather than swabs from the infected area due to the chances of skin contaminants. But biopsy culture is a tough procedure, requires sophistication and costly technique. Hence deep sample collected during surgery is always an alternative for the biopsy culture.

With these, a study was taken to isolate various bacterial etiological agents that cause OM.

\section{Material and Methods}

Settings: It was a cross-sectional, laboratory-based study, conducted in the Department of Microbiology, GSL Medical College in association with the Department of orthopedics.

Duration of study: The study was conducted from June 2019 to Nov 2019.

Sampling method: Random sampling was considered in this study.

Inclusion criteria: Individuals of all ages, both gender who were clinically, radiologically confirmed cases of OM were included in the study. Informed written consent in the presence of the witness was taken from the participants.

Exclusion criteria: Individuals with superficial wound infections and the patients who didn't submit the consent were excluded.

Sample size: All the individuals who satisfy the inclusion criteria during the study period were included in the study.

Ethical approval: Study protocol was approved by the institutional ethical committee.

Bone, tissue, and swabs collected with the utmost sterile precautions were considered. Immediately, the specimen was placed in nutrient broth. Tissue
Samples were vortexed until complete homogenization. Then the specimen was inoculated in 5\% sheep blood agar, Nutrient agar, and MacConkey agar, inoculated plates were incubated at $370 \mathrm{C}$ for 24 hrs [9]. After incubation, growth was classified into gram-positive and gram-negative using gram staining. Gram-positive cocci were further identified using catalase, Coagulase tests.

Whereas gram-negative rods (GNR) were identified further using various biochemical tests such as Oxidase, Catalase, IMViC, Urease, TSI. If required, motility was detected for GNR using a hanging drop experiment. Simultaneously, an antibiotic susceptibility test was performed for various pathogenic isolates using Kirby Bauer disc diffusion method suing ATCC strains as controls.

Statistical analysis: Chi-square test was calculated using SPSS 21.0; $\mathrm{P}<0.05$ was considered statistically significant.

\section{Results}

During the study period total of 72 samples were collected; in this 35 were male and 34 were female and the male-female ratio was 37:35. Out of these 72 cases, 61 were culture positive (CP). In the CP cases, 31 were male, 30 were female and the malefemale ratio was 30:34; statistically, there was no significant difference $(P=0.920241)$ (Table 1$)$.

Table-1: Gender wise culture results among the study participants; $\mathbf{n}(\%)$.

\begin{tabular}{|l|l|l|l|}
\hline \multicolumn{1}{|c|}{ Gender } & \multicolumn{1}{c|}{ CP } & \multicolumn{1}{c|}{ Culture negative (CN) } & \multicolumn{1}{c|}{ Total } \\
\hline Male & $31(43)$ & $6(8.3)$ & $37(51)$ \\
\hline Female & $30(42)$ & $5(7)$ & $35(49)$ \\
\hline Total & $61(85)$ & $11(15)$ & $72(100)$ \\
\hline $\begin{array}{l}\text { Statistical } \\
\text { analysis }\end{array}$ & $\begin{array}{l}\text { Chi square }=0.01 ; P=0.920241 . \\
\text { significant. }\end{array}$ \\
\hline
\end{tabular}

Table-2: Age wise culture results among the study participants; $\mathbf{n}(\%)$.

\begin{tabular}{|l|l|l|l|}
\hline \multicolumn{1}{|c|}{ Age } & \multicolumn{1}{c|}{ CP } & \multicolumn{1}{c|}{ CN } & \multicolumn{1}{c|}{ Total } \\
\hline$<10$ & $4(5.5)$ & $2(2.8)$ & $6(8.4)$ \\
\hline $11-20$ & $6(8.4)$ & $1(1.4)$ & $7(10)$ \\
\hline $21-30$ & $7(10)$ & $1(1.4)$ & $8(11)$ \\
\hline $31-40$ & $13(18)$ & $3(4.2)$ & $16(22.2)$ \\
\hline $41-50$ & $12(17)$ & $2(2.8)$ & $14(19.5)$ \\
\hline $51-60$ & $11(15)$ & $1(1.4)$ & $12(17)$ \\
\hline$>61$ & $8(11)$ & $1(1.4)$ & $9(12.5)$ \\
\hline Total & $61(85)$ & $11(15)$ & $72(100)$ \\
\hline
\end{tabular}

Age-wise, maximum (18\%) CP results were identified in $31-40$ years age group followed by $41-$ 
50 years group (17\%), 51-60 years group (15\%), $>61$ years group (11\%), $21-30$ years group $(10 \%)$ and $<10$ years group (5.5\%). Maximum $(4.2 \%) \mathrm{CN}$ results were identified in 31-40 years of age group followed by $41-50$ years group, $<10$ years group, 2 $(2.8 \%)$ respectively. CN results were similar in 21 30 years group, $51-60$ years group and $>61$ years group, $1(1.4 \%)$ (Table 2$)$.

In this study, group-wise, GNR were isolated maximum (59\%). Isolate wise, Staph. aureus was the maximum number isolated $27 \%$ followed by Pseudomonas aureginosa (23\%), Esch.coli (16\%), Staph. epidermidis (14\%), Proteus species $(11 \%)$ and Klebsiella pneumonia (9.3\%) (Table 3).

Table-3: Various bacterial isolates among the study participants; $\mathbf{n}(\%)$.

\begin{tabular}{|c|c|c|}
\hline Group & Isolate & Total \\
\hline \multirow[t]{2}{*}{ GPC } & Staphylococcus aureus; 20 (27) & \multirow[t]{2}{*}{$31(41)$} \\
\hline & Staphylococcus epidermidis; 11 (14) & \\
\hline \multirow[t]{4}{*}{ GNR } & Pseudomonas aeruginosa; 17 (23) & \multirow[t]{4}{*}{$44(59)$} \\
\hline & Escherichia coli; 12 (16) & \\
\hline & Klebsiella pneumonia; 7 (9.3) & \\
\hline & Proteus species; 8 (11) & \\
\hline \multicolumn{2}{|l|}{ Total } & 75 (100) \\
\hline
\end{tabular}

\section{Discussion}

OM is one of the complex infections because a variety of etiological agents are responsible $[10,11]$. Gender wise, in this report CP results, were more among male which was $43 \%, 42 \%$ respectively in male and female; this was statistically not significant (Table 1). This shows that culture positivity was similar in gender. Thanni LO et al. reported male predominance, which was respectively $61 \%, 39 \%$ among male and female [12] and it was also reported $76 \%$ male patients and $24 \%$ female patients by Suresh babu et al. [13].

The reason for the male predominance was not mentioned by the investigators in the literature. Whereas in this study, all the participants of both genders were involved in outdoor activity. Hence there was no predominance among the gender. The male-female ratio was reported to be 3.16 as per the Neeharika et al. report [14].

Age-wise, the mean age of the study participants was 46.4 years, age was ranged between 6 to 72 years. Maximum $\mathrm{CP}$ cases were identified between 31-60 years age group, which was 36 (50\%). Usually, this is an active age. Because most
Of the study participants were villagers, farming is their main profession. Usually for farmers also 3160 years of age group is the most active age as they involve actively in cultivation. The mean age for OM was reported to be 52.5 years by Wadekar DM et al. study [15].

Vemu et al. reported that OM can occur at any age and can involve any bone [16] and Kao HC et al. in their study mentioned that 13 to 17 years is the common age for hematogenous OM [17]. Whereas acute OM was reported to be common among children, as per the Carek PJ et al. study [18] and 0-16 years was reported to be the common age group for acute OM by Gavilan et al. study [19].

In this study, $41 \%$ were GPC and $59 \%$ were GNR. As per the study by Thinnai LO. et al. report, $S$. aureus was $64.7 \%, 34.7 \%$ were GNR and $8 \%$ were TB arthritis [20]. Where the rate GNR isolation was $74 \%$ according to Sanyuktha et al. report [8].

In 14 numbers of participants, more than one antigen was isolated in this study. Monomicrobial infection was seen reported in $88.2 \%$ and polymicrobial isolates in $11.7 \%$ [15]. Polymicrobial colonization, as well as soft tissues infections, are common in patients with posttraumatic OM.

In continuation, the requirement of the multidisciplinary approach was reported for OM due to the complexity of the infection as well as the etiological agents $[1,11,22]$. Diabetes was another metabolic disorder, among diabetics $10-20 \%$ OM were reported in the literature. But in this study diabetes was not considered.

In this study, Staph. aureus was the predominant $(27 \%)$ isolate followed by Pseudomonas.aerugionasa (23\%). Preist et al. found that $S$. aureus was the predominant isolate. Irrespective of the age, Gavilan MG. et al. mentioned that $S$. aureus was the main causative organism of OM in all age groups [19, 23].

Pappu et al. mentioned that Pseudomonas and Esch. coli were the predominant isolates among the diabetics [24]. No significant drug resistance was identified in this study. The isolates were sensitive to most of the commonly used antibacterial agents.

\section{Limitations}

Small sample size, known consideration of HIV and diabetes status are the major limitations of this research. 


\section{Conclusion}

OM can occur at any age and there is no gender difference. Staph. aureus was a common isolate followed by Pseudomonas.

\section{What does the study add to the existing knowledge?}

Polymicrobial infections are common in OM infections.

\section{Author's contributions}

Dr. P Sunil Kumar: Literature survey, Paper writing, data analysis.

Dr. T Jaya Chandra: Complete idea, Sample collection, Benchwork, statistical analysis, paper writing.

\section{Reference}

01. del Pozo EG, Collazos J, Cartón JA, Camporro D, Asensi $V$. Bacterial osteomyelitismicrobiological, clinical, therapeutic, and evolutive characteristics of 344 episodes. Revista Española de Quimioterapia. 2018;31(3)217-225.

[Crossref]

02. Carvalho VC, Oliveira PR, Dal-Paz K, Paula AP, Félix Cda $S$, Lima AL. Gram-negative osteomyelitis- Clinical and microbiological profile. Braz J Infect Dis. 2012;16(1)63-67.

doi: [Article:https://doi.org/10.1016/S14138670(12)70276-3][Crossref]

03. Radcliffe G. Osteomyelitis- a historical and basic sciences review. Orthop Trauma. $2015 ; 29(4) 243-252$.

doi:

[Article:https://doi.org/10.1016/j.mporth.2015.02.00 2][Crossref]

04. Hogan A, Heppert VG, Suda AJ. Osteomyelitis. Arch Orthop Trauma Surg. 2013;133(9)11831196.

doi: [Article:https://doi.org/10.1007/s00402-0131785-7][Crossref]

05. Abid AS, Ehan AH, Yonis AR. Epidemiological and bacteriological study of chronic osteomyelitis Tikrit. Med J. 2008;14(1)59-62. [Crossref]
06. Dartnell J, Ramachandran M, Katchburian M. Haematogenous acute and subacute paediatric osteomyelitis- a systematic review of the literature. J Bone Joint Surg Br. 2012;94(5)584595.

doi: [Article:https://doi.org/10.1302/0301620x.94b5.28523][Crossref]

07. Vazquez M. Osteomyelitis in children. Curr Opin Pediatr. 2002;14(1)112-115.

doi: [Article:https://doi.org/10.1097/00008480200202000-00020][Crossref]

08. Shettigar S, Shenoy S, Bhat S, Rao P. Microbiological Profile of Deep Tissue and Bone Tissue in Diabetic Foot Osteomyelitis. J of Clil and Diagic Rese. 2018;12(6)DC20-DC22.

doi:

[Article:https://doi.org/10.7860/JCDR/2018/35462.1 1597][Crossref]

09. Chandra TJ, Lakshmi Prasanna, AV Rao. A study on isolation and identification of nosocomial infections causing bacteria on mobile phones of health care workers. Calicut Med J. 2011;9(1)e2.

[Crossref]

10. Chihara S, Segreti J. Osteomyelitis. Dis Mon. 2010;56(1)5-31.

doi:

[Article:https://doi.org/10.1016/j.disamonth.2009.07 .001][Crossref]

11. Tulner SAF, Schaap GR, Strackee SD, Besselaar $\mathrm{PP}$, Luitse JSK, Marti RK. Long-term results of multiple-stage treatment for posttraumatic osteomyelitis of the tibia. J Trauma. 2004;56(3)633-642.

doi:

[Article:https://doi.org/10.1097/01.ta.0000112327.5 0235.0a][Crossref]

12. Solagberu BA, Duze AT, Ofoegbu C P, Adekanye $A O$, Odelowo EO. Surgical morbidity and mortality pattern in the accident and emergency room-a preliminary report. Afr J Med Med Sci. 2000;29(3)315-318.

[Crossref]

13. Tummala VS, Surapaneni SB, Pigilam S. Bacteriological study of orthopaedic infections. Int J Orthopaed. 2017;3(2)90-92.

doi:

[Article:https://doi.org/10.22271/ortho.2017.v3.i2b.1 7][Crossref] 
14. Kao HC, Huang YC, Chiu CH, Chang LY, Lee ZL, Chung PW et al. Acute hematogenous osteomyelitis and septic arthritis in children. J Microbiol Immunol Infect. 2003;36;260-265.

[Crossref]

15. Prieto-Pérez L, Pérez-Tanoira R, Petkova-Saiz E, Pérez-Jorge C, Lopez-Rodthop. Osteomyelitis- a descriptive study. Clin Orthop Surg. 2014;6(1)20-25.

doi:[Article:https://doi.org/10.4055/cios.2014.6.1.

20][Crossref]

16. Gavilán MG, López JB, Artola Neeharika B, Vinod R, Rakesh G. A study of aerobic bacterial profile and their antibiogram in patients with chronic osteomyelitis with special references to staphylococcus aureus. Ind J Microbiol Res. 2019;6(4)350-354.

doi: [Article:http://doi.org/10.18231/j.ijmr.2019.074] [Crossref]

17. Wadekar DM, Anuradha K, Venkatesha D. Chronic osteomyelitis: Aetiology and antibiotic susceptibility pattern. Int J Recent Trends Sci Technol. 2014;9(3)337-340.

[Crossref]

18. Vemu L, Sudhaharan S, Mamidi N, Chavali P. Need for appropriate specimen for microbiology diagnosis of chronic osteomyelitis. J Lab Physicians. 2018;10(1)21-25.

doi:[Article:https://doi.org/10.4103/jlp.jlp_14_17]

[Crossref]
19. BS. Peculiarities of osteoarticular infections in children. Best Pract Res Clin Rheumatol. 1999;13(1)77-94.

doi:[Article:http://doi.org/10.1053/berh.1999.0007]

[Crossref]

20. Thanni LOA, Kehinde OA. Trauma at a Nigerian teaching hospital- pattern and documentation of presentation. African Health Sci. 2006;6(2)104107.

[Crossref]

21. Carek PJ, Dickerson LM, Sack JL. Diagnosis and management of osteomyelitis. Am Fam Physician. 2002;63(12)2413-2420.

[Crossref]

22. Smith IM, Austin OMB, Batchelor AG. The treatment of chronic osteomyelitis- a 10-year audit. J Plast Reconstr Aesthet Surg. 2006;59(1)11-15.

doi:[Article:https://doi.org/10.1016/j.bjps.2005. 07.002][Crossref]

23. Priest $\mathrm{DH}$, Peacock JE jr. studies on haematogenous vertebral osteomyelitis due to Staphylococcus aureus in adults South. Med J. 2006;98(9)854-862.

doi:[Article:https://doi.org/10.1097/01.smj.000016 8666.98129.33][Crossref]

24. Pappu AK, Sinha A, Johnson A. Microbiological profile of diabetic foot ulcer. Calicut Med J. 2011;9(3)e1-e4.

[Crossref] 